\title{
ANALISIS MISKONSEPSI SISWA KELAS VIII PADA MATA PELAJARAN IPA TERPADU DI SMP N 3 KOTA KUPANG TAHUN AJARAN 2018/2019 (Misconception Analysis Of Grade Viii Students In Integrated Science Students In Smp N 3 Kupang City In The 2018/2019 Academic Year) \\ Simson Obhetan ${ }^{1}$, Agus Maramba Meha1*, Yonatan Foeh ${ }^{2}$ \\ ${ }^{1}$ Program Studi Pendidikan Biologi-Universitas Kristen Artha Wacana ${ }^{2}$ Institut Agama Kristen Negeri Kupang
}

Coressponding Author: us.meha17@gmail.com*

\begin{abstract}
ABSTRAK
Penelitian ini bertujuan untuk menganalisis miskonsepsi pada materi biologi dari mata pelajaran IPA Terpadu di SMP N 3 Kota Kupang tahun ajaran 2018/2019. Metode penelitian yang dipakai ialah metode kualitatif dengan desain penelitian deskriptif. Pengumpulan data untuk mengidentifikasi dan mendeskripsikan miskonsepsi pada siswa dilakukan dengan menggunakan soal pilihan ganda berbasis teknik tes diagnostik yang dilengkapi dengan Certainty of Response Index (CRI) dan wawancara. Untuk menganalisa data kualitatif dalam penelitian ini menggunakan rumus yaitu $p=f / n \times 100$ untuk mengetahui persentase siswa yang mengalami paham konsep, miskonsepsi dan tidak paham konsep. Data kemudian direduksi, disajikan, dan diberi kesimpulan. Pelajaran yang diambil untuk mengidentifikasi miskonsepsi siswa yitu sistem pernapasan pada manusia. Intrumen tes terdiri dari 10 soal pilihan ganda dan 5 soal isian yang diberikan untuk menganalisis miskonsepsi siswa. Perkembangan kognitif siswa sangat berpengaruh pada pola pemahaman siswa itu sendiri hal ini ditandai dengan besarnya persentase siswa yang mengalami miskonsepsi yang terjadi pada ranah penerapan (C3) yakni pada soal no 7 dengan total miskonsepsi mencapai $70.97 \%$ diikuti soal no 6 dengan total $54.83 \%$ dan soal nomer 8 dengan total $45.16 \%$, diikuti ranah pemahaman (C2) yakni pada soal no 3 dengan persentase sebanyak $41.93 \%$ dan persentase terendah yaitu pada ranah pengetahuan (C1) pada soal no 15 dengan persentase 19.35\%. Miskonsepsi yang dialami siswa beragam, dimana pola pemahaman siswa pun berbeda-beda dikarenakan beberapa faktor yaitu faktor internal berupa kondisi siswa itu sendiri serta eksternal yakni unjuk kerja guru dalam pembelajaran.
\end{abstract}

Kata Kunci: Miskonsepsi, Tes Diagnostik, Siswa

\begin{abstract}
This study aims to analyze misconceptions in biological material from Integrated Science subjects at SMP N 3 Kota Kupang in the 2018/2019 academic year. The research method used is a qualitative method with a descriptive research design. Data collection to identify and describe misconceptions in students was carried out using multiple-choice questions based on diagnostic test techniques equipped with a Certainty of Response Index (CRI) and interviews. To analyze the qualitative data in this study, a formula was used, namely, $p=f / n \times 100$ to determine the percentage of students who experienced conceptual understanding, misconceptions, and did not understand concepts. The data is then reduced, presented, and concluded. Lessons taken to identify students' misconceptions, namely the respiratory system in humans. The test instrument consists of 10 multiple choice questions and 5 questionnaires that are given to analyze student misconceptions. The cognitive development of students is very influential on the pattern of students' understanding itself, this is indicated by the large percentage of students who experience misconceptions that occur in the realm of application (C3), namely in question number 7 with total misconceptions reaching $70.97 \%$ followed by question number 6 with a total of $54.83 \%$ and questions number 8 with a total of $45.16 \%$, followed by the realm of understanding (C2), namely in question number 3 with a percentage of $41.93 \%$ and the lowest percentage in the domain of knowledge (C1) in question number 15 with a percentage of $19.35 \%$. There are various misconceptions experienced by students, where students 'understanding patterns differ due to several factors, namely internal factors in the form of students' conditions and external, namely teacher performance in learning.
\end{abstract}

Keywords: Misconceptions, Diagnostic Tests, student 


\section{PENDAHULUAN}

Pendidikan memiliki peran strategis dalam mencerdaskan dan memajukan sebuah bangsa. Oleh karena itu sekolah sebagai tempat berlangsungnya proses pendidikan mengambil bagian yang besar untuk mewujudkannya. Dalam pelaksanaan pembelajaran dengan kurikulum 2013 di sekolah, siswa dituntut untuk terlibat secara aktif dan mandiri dalam mengembangkan potensi diri. Sedangkan guru memiliki peran sebagai fasilitator dan membimbing siswa agar dapat memahami konsep yang dipelajari. Wahyudi (2012) mengungkapkan bahwa peranan sebagai seorang pengajar, guru harus menciptakan proses pembelajran yang efektif salah satu cirinya yaitu merangsang siswa untuk mempelajari berbagai cara belajar (learning how to learn). Keberhasilan siswa dalam memahami materi pelajaran, tergantung pada guru sebagai pembimbing yang harus bertindak sebagai motivator dan fasilitator yang baik. Dengan keterampilan dalam proses pembelajaran seseorang akan mampu belajar mandiri, mengembangkan diri sendiri, dan belajar sepanjang hayat (Ibrahim, 2010). Siswa yang mandiri dalam mengembangkan diri serta mendapatkan bimbingan dari guru dalam proses pembelajaran akan memahami konsep materi dengan baik dan menghindari terjadinya miskonsepsi.

Menurut Fowler dalam Suparno (2005) menyatakan bahwa "Miskonsepsi diartikan sebagai pengertian yang tidak akurat tentang konsep, penggunaan konsep yang salah, klasifikasi contohcontoh yang salah, kekacauan konsep-konsep yang berbeda dan hubungan hirarkis konsep-konsep yang tidak benar". Selanjutnya Soedjadi (2000) menyatakan bahwa Miskonsepsi timbul karena adanya prakonsepsi, prakonsepsi adalah konsep awal yang dimiliki seseorang tentang sesuatu obyek. Dalam mencegah terjadinya miskonsepsi pada siwa, guru harus berupaya menciptakan dan mengembangkan proses pembelajaran yang lebih aktif dan menyenangkan sehingga siswa dapat terlibat secara aktif dan berusaha dalam memahami konsep materi yang dipelajari.

Hasil pengamatan proses pembelajaran di SMP N 3 Kupang ditemukan bahwa guru kurang memperhatikan proses pembelajaran yang sudah direncanakan, dikarenakan kurang menggunakan waktu pembelajaran secara baik, selama pelajaran berlangsung siswa hanya mengandalkan buku dan LKS yang secara isi materinya sangat minim, dan masalah berikut siswa tidak memiliki kemauan dan inisiatif dalam menggali informasi dari sumber yang berbeda, hal ini mengakibatkan pemahaman akan materi menjadi sangat minim. Pemahaman materi yang didapat tidak sejalan dengan konsep inilah dapat menyebabkan terjadinya miskonsepsi pada siswa. Berdasarkan latar belakang yang telah dipaparkan maka perlu dilakukan penelitian mengenai analisis miskonsepsi siswa kelas viii pada mata pelajaran ipa terpadu di SMPN 3 Kupang.

\section{METODE PENELITIAN}

Penelitian ini dilaksanakan di SMP N 3 Kupang pada Tahun ajaran 2018/2019. Metode yang digunakan adalah metode kualitatif, dengan desain penelitian deskriptif, dikarenakan pada hasil penelitian ini memberikan uraian yang dimuat dalam bentuk analisis yang berkaitan dengan miskonsepsi siswa. Prosedur Penelitian diawali dengan tahap persiapan yaitu peneliti menyiapkan instrumen test berupa pilihan ganda kemudian memilih kelas yang menjadi subjek dalam penelitian. Selanjutnya Tahap Pelaksanaan dimana peserta didik diminta untuk mengisi jawaban berupa tes pilihan ganda disertai dengan alasan.

Teknik pengumpulan data yang digunakan dalam penelitian ini yakni menggunakan tes tertulis, wawancara dan observasi. Tes disertai dengan teknik $C R I$ menggunakan skala enam (0-5) yang dikembangkan oleh Saleem Hasan (1999) dengan kriteria opsi CRI yang tersedia pada Tabel 1.

Tabel 1. Opsi skala 6 tingkatan

CRI Kriteria


$1 \quad$ untuk jawaban agak tahu (almost guess answer).

2 untuk jawaban yang tidak yakin (not sure).

3 untuk jawaban yang yakin (sure).

$4 \quad$ untuk jawaban yang agak yakin (almost certain).

5 untuk jawaban yang pasti/ sangat yakin (certain).

Angka 0 menunjukkan tingkat keyakinan yang dimiliki siswa sangat rendah, siswa menjawab pertanyaan dengan cara menebak jawaban secara total. Sedangkan angka 5 menunjukkan tingkat kepercayaan siswa dalam menjawab pertanyaan (soal) dengan keyakinan sangat tinggi dan mereka menjawab pertanyaan dengan pengetahuan atau konsep-konsep yang benar tanpa ada unsur tebakan sama sekali sehingga soal yang diberikan tersebut dapat disesuaikan dengan kemungkinan pola jawaban siswa seperti yang tersedia di Tabel 2 .

Tabel 2 Kemungkinan pola jawaban siswa dan kategorinya

\begin{tabular}{cllc}
\hline \multirow{2}{*}{ Jawaban } & Alasan & \multicolumn{1}{c}{ Deskripsi } & Ket \\
\hline Benar & Benar & Paham Konsep dengan baik & PK \\
Benar & Salah & Miskonsepsi & $\mathrm{M}$ \\
Salah & Salah & Tidak Tahu Konsep & TTK \\
Salah & Benar & Miskonsepsi & $\mathrm{M}$ \\
\hline
\end{tabular}

(Tayubi, 2005).

Teknik CRI tidak hanya dapat mengidentifikasi miskonsepsi siswa, tetapi juga dapat membedakan siswa yang tahu konsep dan siswa yang tidak tahu konsep, hanya dengan melihat jawaban dan skala keyakinan yang diberikan siswa seperti ditunjukkan pada Tabel 2 menunjukkan empat kemungkinan kombinasi dari jawaban (benar atau salah) dan CRI (tinggi atau rendah) untuk tiap responden secara individu dalam menjawab pertanyaan (soal). Untuk seorang responden dan untuk suatu pertanyaan yang diberikan, jawaban benar dengan CRI rendah menandakan tidak tahu konsep, dan jawaban benar dengan CRI tinggi menunjukkan penguasaan konsep yang tinggi. Jawaban salah dengan CRI rendah menandakan tidak tahu konsep, sementara jawaban salah dengan CRI tinggi menandakan terjadinya miskonsepsi.

\section{Teknik Analisis Data}

Data yang diperoleh dari teknik $\mathrm{CRI}$ akan dianalisis menggunakan rumus persentase yang dikemukakan oleh Arikunto (2005), yaitu :

$$
\begin{array}{cl}
\mathrm{p}=\frac{f}{n} \times 100 \% & \\
\text { Keterangan } & : \\
\mathrm{P} & \text { : Nilai persentase jawaban responden } \\
\mathrm{f} & \text { : Frekuensi jawaban responden } \\
\mathrm{n} & \text { : Jumlah responden } \\
100 \% & \text { : Bilangan konstan }
\end{array}
$$


Penentuan miskonsepsi siswa berdasarkan hasil tes dan disesuaikan pada tabel presntase miskonsepsi dengan kriteria paham konsep, miskonsepsi dan tidak paham konsep. selanjutnya analisis selama di lapangan dilakukan dengan model Miles and Huberman melalui Data Rediction (Reduksi data), Data display (Penyajian data) dan Conclusion Drawing/verivication (kesimpulan), (Sugiyono, 2010).

\section{HASIL PENELITIAN}

Berdasarkan hasil olahan data menggunakan teknik Certainty of Response Index (CRI) menunjukkan bahwa miskonsepsi terjadi pada setiap soal yang diberikan, namun dari 15 soal yang diberikan ada soal yang memiliki persentase miskonsepsi yang sangat rendah serta soal yang memiliki tingkatan miskonsepsi yang sangat tinggi.) secara keseluruhan hasil tes siswa dikelompokkan dalam tiga kelompok yaitu siswa yang Tahu Konsep (TK), Miskonsepsi (MK), dan Tidak Tahu konsep (TTK) dengan skala CRI yang berbeda-beda

\section{Data Miskonsepsi Siswa}

Tes miskonsepsi dalam studi kasus diberikan pada siswa SMP N 3 Kupang yang sudah pernah mendapatkan pengalaman belajar mengenai sistem pernapasan di kelas. Jumlah tes yang diberikan sebanyak 15 butir soal. Siswa akan terkategori miskonsepsi apabila memberikan jawaban salah. Untuk melihat rata-rata miskonsepsi siswa dari masing-masing subkonsep pada Tabel 3.

Tabel 3 . Persentase Miskonsepsi Siswa

\begin{tabular}{ccccccc}
\hline Butir Soal & \multicolumn{3}{c}{$\begin{array}{c}\text { Frekuensi jawaban siswa } \\
\text { berdasarkan butir soal }\end{array}$} & \multicolumn{3}{c}{ Persentase (\%) } \\
\cline { 2 - 7 } & PK & MK & TTK & PK & MK & TTK \\
1 & 27 & - & 4 & 87.09 & - & 12.90 \\
2 & 19 & - & 12 & 61.29 & - & 38.70 \\
3 & 9 & 14 & 8 & 29.03 & 45.16 & 25.80 \\
4 & 31 & - & - & 100 & - & - \\
5 & 28 & - & 3 & 83.87 & - & 16.12 \\
6 & 10 & 17 & 4 & 32.25 & 54.83 & 12.90 \\
7 & - & 22 & 9 & - & 70.97 & 29.03 \\
8 & 6 & 13 & 12 & 19.35 & 41.39 & 38.70 \\
9 & 20 & - & 8 & 64.51 & - & 25.80 \\
10 & 27 & - & 4 & 87.09 & - & 12.90 \\
11 & 28 & - & 3 & 90.32 & - & 9.67 \\
12 & 28 & - & 3 & 90.32 & - & 9.67 \\
13 & 29 & - & 2 & 93.58 & - & 6.45 \\
14 & 30 & - & 1 & 96.77 & - & 3.22 \\
15 & 25 & 6 & - & 80.65 & 19.35 & - \\
\hline
\end{tabular}

Miskonsepsi siswa terjadi pada soal yang bervariasi. Jika ditinjau berdasarkan butir soal yang paling banyak ditemui miskonsepsi pada butir soal nomor 7 sebanyak 22 siswa mengalami miskonsepsi atau sebesar $70.97 \%$. Sedangkan soal dengan miskonsepsi terendah pada soal nomor 15 sebanyak 6 siswa yang mengalami miskonsepsi atau sebesar $19.35 \%$. Dan untuk lebih jelasnya urutan miskonsepsi dari yang tertinggi sampai terendah berdasarkan butir soalnya, disajikan dalam Tabel 4.

Tabel 4. Persentase Miskonsepsi siswa berdasarkan Butir Soal Yang Memiliki Miskonsepsi Tertinggi.

Berdasarkan data yang berhasil dikumpulkan, bahwa persentase miskonsepsi siswa paling besar terdapat pada soal nomor 7 yaitu $70.67 \%$. butir soal nomor 7 merupakan bentuk soal untuk 45 


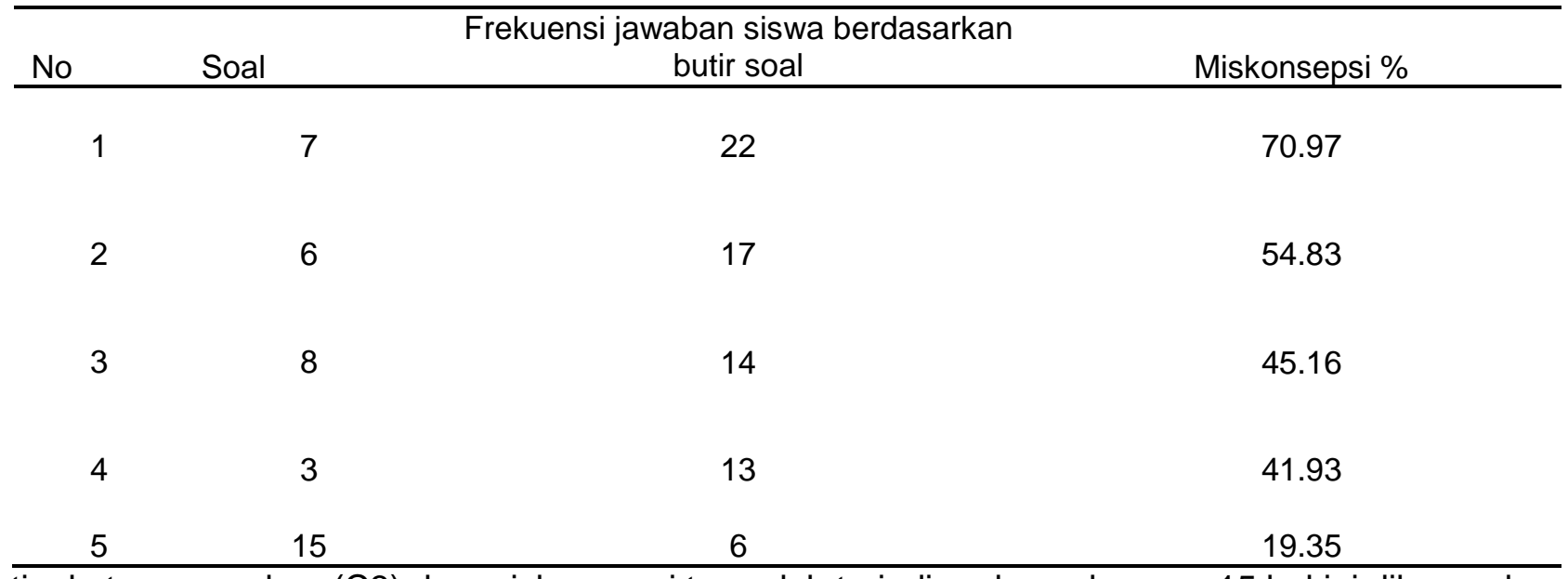

tingkat menerapkan (C3) dan miskonsepsi terendah terjadi pada soal nomor 15 hal ini dikarenakan bentuk soalnya pada tingkat mengingat (C1).

\section{Klasifikasi Miskonsepsi Siswa}

Miskonsepsi yang dialami siswa terdapat pada materi sistim pernapasan pada manusia hal ini diketahui dari hasil yang sudah diuraikan pada tabel yang telah tersedia. Dan untuk mengetahui miskonsepsi berdasarkan aspek kognitif siswa akan dideskripsikan berdasarkan soal dengan kategori miskonsepsi tertinggi dan jawaban berdasarkan hasil wawancara siswa yang mengalami miskonsepsi.

\section{a.Miskonsepsi Siswa pada Soal Nomor 7}

$\underline{\text { Tabel 5. Miskonsepsi Siswa Pada Butir Soal Nomor } 7}$

$\begin{array}{lll}\text { Soal Konsep Miskonsepsi } & \end{array}$

Tujuan pokok Pernapasan bagi makhluk hidup yaitu
Bernapas merupakan pergerakan udara ke dalam dan keluar paru-paru. Di dalam udara pernapasan terdapat oksigen yang akan digunakan untuk oksidasi biologi tubuh.
1. Bernapas

2. untuk mendapatkan oksigen

3. kalau manusia tidak mendapatkan oksigen maka manusia akan mati

4. kalau tidak bernapas maka manusia akan mati

5. karena itu adalah tujuan makluk hidup untuk bisa hidup

6. karena pada saat bernapas menghirup oksigen.

7. karena jika manusia tidak mendapatkan oksigen maka manusia tidak akan hidup

Miskonsepsi pada soal nomor 7 mengacu pada keterlibatan keseharian manusia dalam hal ini mengenai pernapasan. Soal yang diberikan bagi siswa ketika ditanyakan "Tujuan Pokok Pernapasan Bagi Makluk Hidup" pertanyaan yang diajukan yakni pada jenjang penerapan (C3). Ini diartikan sebagai kemampuan menerapkan informasi pada situasi nyata dimana peserta didik mampu menerapkan pemahamanya sehingga dijenjang ini peserta didik dituntut untuk dapat menerapkan konsep dan prinsip yang ia miliki. Pada hasil yang telah didapat bahwa pada soal no 7 sebanyak 22 peserta didik yang mengalami miskonsepsi atau sebesar $70.67 \%$. Soedjadi (2000) 
Indigenous Biologi

Jurnal pendidikan dan Sains Biologi

3(1) 2020

menjelaskan bahwa miskonsepsi terjadi akibat adanya prakonsepsi atau pemahaman awal yang diperoleh seseorang.

\section{b.Miskonsepsi Siswa pada Soal Nomor 6}

Tabel 6. Miskonsepsi Siswa Pada Butir Soal Nomor 6

$\begin{array}{lll}\text { Pertanyaan } \quad \text { Konsep } \quad \text { Miskonsepsi } & \end{array}$

\begin{tabular}{|c|c|c|}
\hline \multirow{4}{*}{$\begin{array}{l}\text { Apa yang } \\
\text { akan terjadi } \\
\text { bila Udara } \\
\text { dari luar } \\
\text { akan masuk } \\
\text { ke paru-paru } \\
?\end{array}$} & \multirow{4}{*}{$\begin{array}{l}\text { Berkontraksinya otot antar } \\
\text { tulang rusuk sehingga rongga } \\
\text { dada membesar, akibatnya } \\
\text { tekanan dalam rongga dada } \\
\text { menjadi lebih kecil daripada } \\
\text { tekanan di luar sehingga } \\
\text { udara luar yang kaya oksigen } \\
\text { akan masuk. }\end{array}$} & \multirow{2}{*}{$\begin{array}{l}\text { 1. karena saat kita bernapas tulang } \\
\text { rusuk kita pun ikut terangkat } \\
\text { 2.karena pada saat kita menghirup } \\
\text { udara, paru-paru ita akan merespon } \\
\text { 3. karena kalau tulang rusuk kita tidak } \\
\text { terangkat maka kita tidak bisa } \\
\text { menghirup }\end{array}$} \\
\hline & & \\
\hline & & 4. karena pada saat kita berna \\
\hline & & \\
\hline
\end{tabular}

Miskonsepsi pada soal nomor 6 mengacu pada keterlibatan keseharian manusia dalam hal ini mengenai pernapasan. Soal yang diberikan bagi siswa ketika ditanyakan "Apa yang akan terjadi bila udara dari luar akan masuk ke paru-paru ?". Pertanyaan yang di ajukan yakni pada jenjang penerapan (C3). Jenjang ini diartikan sebagai kemampuan menerapkan informasi pada situasi nyata dimana peserta didik mampu menerapkan pemahamanya sehingga pada jenjang ini peserta didik dituntut untuk dapat menerapkan konsep dan prinsip yang dimiliki. Pada hasil yang didapat Sebanyak $54.83 \%$ atau sebanyak 17 siswa mengalami miskonsepsi.

\section{c.Miskonsepsi Siswa pada Soal Nomor 3}

Tabel 7. Miskonsepsi siswa pada butir soal nomor 3

$\begin{array}{lll}\text { Pertanyaan } \quad \text { Konsep } \quad \text { Miskonsepsi } & \end{array}$

\begin{tabular}{|c|c|c|}
\hline $\begin{array}{l}\text { Apa yang } \\
\text { kalian tau } \\
\text { tentang } \\
\text { Kapasitas } \\
\text { vital paru- } \\
\text { paru }\end{array}$ & $\begin{array}{l}\text { Merupakan jumlah udara } \\
\text { maksimumyang bisa dkeluarkan } \\
\text { oleh paru-paru atau Sebanyak } \\
\text { banyaknya udara yang mampu } \\
\text { dikeluarkan manusia dari paru } \\
\text { parunya. Namun sebelumnya, ia } \\
\text { sudah mengisi udara pada paru } \\
\text { paru secara maksimum, Lalu } \\
\text { melepaskan sebanyak banyaknya. }\end{array}$ & $\begin{array}{l}\text { 1. Karena kita menarik napas } \\
\text { dalam-dalam maka paru-paru } \\
\text { kita akan penuh } \\
\text { 2. Semua udara yang telah keluar } \\
\text { dari paru-paru } \\
\text { 3. Volume tidal yang dapat dihirup } \\
\text { dan masukdalam paru-paru }\end{array}$ \\
\hline
\end{tabular}

Soal nomor 3 mengacu pada jenjang pemahaman yaitu dimana pada jenjang pemahaman (C2). Hal ini diartikan sebagai kemampuan dalam memahami materi yang dipelajari yaitu Translasi, interprestasi dan eksplorasi. Soal yang diberikan yaitu "Pengertian dari kapasitas vital paru-paru". Sebanyak $45.16 \%$ atau sebanyak 14 siswa yang mengalami miskonsepsi.

\section{d.Miskonsepsi Siswa pada Soal Nomor 8}

Tabel 8. Miskonsepsi siswa pada butir soal nomor 8 


\section{$\begin{array}{lll}\text { Pertanyaan } & \text { Konsep } & \text { Miskonsepsi }\end{array}$}

Mekanisme dari Pernapasan yang pernapasan perut

mekanismenya melibatkan aktifitas otototot diafragma yang membatasi rongga perut dan rongga dada
1. Otot perut akan manahan dan udara dihembuskan

2. Rongga pada otot perut akan mengalami kontraksi

3. Semua udara yang telah keluar dari perut

Miskonsepsi pada soal nomor 8 mengacu pada jenjang penerapan (C3). Kemampuan ini diartikan sebagai menerapkan informasi pada situasi nyata dimana peserta didik mampu menerapkan pemahamanya sehingga pada jenjang ini peserta didik dituntut untuk dapat menerapkan konsep dan prinsip yang ia miliki. Soal yang diberikan yaitu mengenai pernapasan perut. "Mekanisme dari pernapasan perut". Sebanyak $41.39 \%$ atau sebanyak 13 siswa yang mengalami miskonsepsi.

e.Miskonsepsi Siswa pada Soal Nomor 15

Tabel 9. Miskonsepsi siswa pada butir soal nomor 15

$\begin{array}{lll}\text { Pertanyaan } & \text { Konsep } & \text { Miskonsepsi }\end{array}$

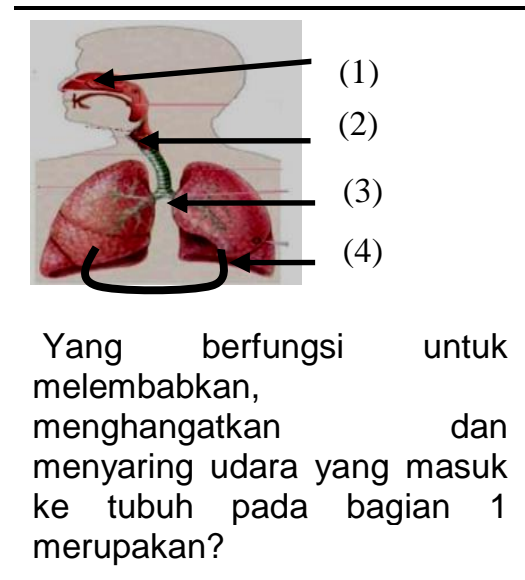

Rongga hidung berfungsi untuk 1. Hidung melembabkan, menghangatkan, dan menyaring (filter) udara yang masuk ke tubuh.

Miskonsepsi pada soal nomor 15 mengacu pada jenjang pengetahuan (C1). Kemampuan ini diartikan sebagai cara untuk mengingat kembali materi yang telah dipelajari. Soal yang diberikan yaitu mengenai fungsi organ pada sbuah gambar yang telah tersedia. Pada soal ini sebanya $19.35 \%$ atau sebanyak 6 siswa yang mengalami miskonsepsi.

\section{PEMBAHASAN}

Pola jawaban siswa menunjukkan miskonsepsi yang terjadi bukan hanya dari pola alasan yang salah mengenai jawaban yang mereka berikan, siswa cendrung hanya menebak jawaban pada soal pilihan ganda dan tidak mengerti apa sebenarnya konsep dari soal yang dikerjakan. berdasarkan temuan yang didapatkan penyebab miskonsepsi pada siswa diantaranya siswa cenderung dituntut berpikir cepat. hal ini bisa kita klasifikasikan dalam suatu keadaan dimana siswa menjawab beberapa pertanyaan yang menurut mereka itu adalah benar dan sesuai dengan pemahaman yang mereka miliki sehingga mengesampingkan sebuah konsep yang benar mengenai materi.

Tolak ukur terjadinya miskonsepsi pada siswa meliputi beberapa aspek seperti yang dapat dilihat dari struktur kalimat pada saat memberikan alasan dalam memilih jawaban seperti pada jawaban soal nomor 3 dan 15 dimana siswa mengalami kekeliruan dalam berpendapat. Pada soal nomor 3 berbunyi "Apa yang kalian tau tentang Kapasitas vital paru-paru" sebanyak 14 siswa 
Indigenous Biologi

Jurnal pendidikan dan Sains Biologi

3(1) 2020

mengalami miskonsepsi. Siswa cendrung menjawab berdasakan pengetahuannya sendiri tanpa melihat konsep yang benar. Miskonsepsi lainnya juga terdapat pada siswa yang memberikan jawaban yang singkat, jika dilihat dari bentuk pertanyaan pada tingkatan penerapan (C3), yang seharusnya membutuhkan jawaban yang memiliki alasan. Hal ini terjadi pada soal nomor 7 dengan bunyi pertanyaan "tujuan pokok pernapasan bagi makhluk hidup", rata-rata siswa hanya menjawab secara singkat yaitu "bernapas" "mendapatkan oksigen". Miskonsepsi dapat terjadi ketika siswa sedang berusaha membentuk pengetahuan dengan cara menerjemahkan pengalaman baru dalam bentuk konsepsi awal (NSTA, 2013). Lebih lanjut Suparno, (2005) menjelaskan penyebab miskonsepsi pada siswa diantaranya siswa itu sendiri, guru, buku teks, dan metode pembelajaran yang digunakan oleh siswa dalam pembelajaran. Hal ini sejalan dengan penelitian yang dilakukan Mentari, et al. (2017) menyatakan bahwa faktor penyebab miskonsepsi pada siswa bersumber dari siswa, guru, dan sumber belajar (LKS).

Miskonsepsi siswa pada soal nomor 7,6, dan 8 merupakan aspek kemampuan menerapkan (C3) yang paling besar mengalami miskonsepsi. Hal ini disebabkan karena tingkat kesulitan soal lebih pada tingkatan C3 lebih tinggi jika dibandingkan dengan butir soal pada aspek mengingat dan memahami. Miskonsepsi siswa masih menjadi permasalah utama hampir pada semua materi pembelajaran, seperti pada hasil penilitian yang dilakukan oleh Mustakim, dkk (2014) ditemukan bahwa persentase siswa yang mengalami miskonsepsi sebesar 37,69 \% dan persentase tersebut lebih kecil dibandingkan dengan persentase siswa yang tidak tahu konsep. miskonsepsi yang dialami oleh siswa dapat disebabkan oleh cara belajar siswa yang hanya menghafal suatu konsep tanpa menghubungkan antara konsep yang satu dengan konsep yang lainnya.

Pola jawaban siswa dilihat bahwa miskonsepsi yang dialami bukan hanya dari pola alasan yang salah mengenai jawaban yang mereka berikan, akan tetapi tidak sedikit siswa yang hanya menebak jawaban pada soal pilihan ganda dan tidak mengerti apa sebenarnya konsep dari soal yang mereka kerjakan bahkan tidak menjawab apa yang ditanyakan, hal ini dikarenakan siswa sudah lupa akan materi dan tidak mengingat kembali materi yang telah diajarkan. Menurut Comins (Ariandini, 2013) miskonsepsi dapat disebabkan oleh penalaran siswa yang tidak lengkap atau salah. Hal ini menyebabkan siswa mengambil kesimpulan yang salah untuk konsep tersebut, sehingga menyebabkan miskonsepsi.

Perkembangan kognitif siswa sangat berpengaruh pada pola pemahaman siswa itu sendiri hal ini ditandai dengan persentase siswa yang mengalami miskonsepsi sangat besar yakni pada dimensi kognitif penerapan (C3). Hal ini menjadi permasalahan utama yang membutuhkan pemecahan masalah oleh guru matapelajaran terkait model pembelajaran serta media pembelajaran yang digunakan sehingga dapat mengoptimalkan pemahaman konsep siswa.

\section{KESIMPULAN}

Berdasarkan hasil analisis data diagnostik (CRI) menunjukkan bahwa siswa mengalami miskonsepsi pada materi sistem pernapasan, dimana pada butir soal nomor 7 siswa mengalami miskonsepsi teringgi yaitu sebesar $70.97 \%$ diikuti soal nomor 6 sebesar $54.83 \%$, kemudian soal nomor 3 sebesar $45.16 \%$ diikuti soal nomor 8 sebesar $41.39 \%$ dan miskonsepsi siswa pada soal nomor 15 yaitu sebsar $18.35 \%$.

\section{DAFTAR PUSTAKA}

Arikunto, S. (2005). Prosedur Penelitian Ilmiah. Rineka cipta, Jakarta

Ariandini, D., Anggraeni, S., \& Aryani, A. (2013). Identifikasi Miskonsepsi Siswa SMP pada Konsep Fotosintesis Melalui Analisis Gambar. Jurnal Pengajaran MIPA, 18(2), 178-184.

Hasan, S., D. Bagayoko, D., and Kelley, E. L., (1999), Misconseptions and the Certainty of Response Index (CRI), Phys. Educ. 34(5), pp. 294 -299.

Ibrahim Indrawijaya A.. 2010. Teori Perilaku, dan Budaya Organisasi Indonesia. Bandung: Refika Aditama

Mustakim, T. A., Zulfiani, Z., \& Herlanti, Y. (2014). Identifikasi miskonsepsi siswa dengan menggunakan metode certainty of response index (cri) pada konsep fotosintesis dan respirasi tumbuhan. Edusains, 6(2), 145-152. 
Mentari, L., Suardana, I. N., \& Subagia, I. W. (2017). Analisis Miskonsepsi Siswa SMA pada Pembelajaran Kimia untuk Materi Larutan Penyangga. Jurnal Pendidikan Kimia Undiksha, 1(1).

Suparno Paul. 2005. Miskonsepsi dan Perubahan Konsep dalam Pendidikan Fisika. Jakarta : PT Grasindo.

Soedjadi. 2000. Kiat Pendidikan Matematika di Indonesia. Jakarta : Ditjen Dikti Depdiknas

Sugiyono, P. D. (2010). Metode penelitian pendidikan. Pendekatan Kuantitatif.

Tayubi, Y. R. (2005). Identifikasi miskonsepsi pada konsep-konsep fisika menggunakan Certainty of Response Index (CRI). Mimbar Pendidikan, 3(24), 4-9.

Wahyudi, Imam. 2012. Mengejar Profesionalisme Guru. Jakarta. Prestasi Pustaka 